\title{
Management of impacted maxillary canines: a case report
}

\section{Manejo de caninos maxilares impactados: relato de caso}

\author{
Sridhar Premkumar ${ }^{1}$, Shameer SFs ${ }^{2}$, Marcos Roberto Tovani-Palone ${ }^{3 *}$
}

\begin{abstract}
Canine impactions correspond to frequent findings in the general population. Maxillary canines are of great important for both aesthetic and functional aspects, since they provide support of the lip and facial muscles, act as important guideposts in occlusion, play a vital role as tissue support at the corner of the mouth and their position is in the turning point of the dental arch. A failure of canine eruption due to impaction will affect the occlusion and may even influence the psychological development of the affected people. At present, different guidelines for management of impacted maxillary canines can be encountered in the literature, but there is still no absolute consensus among scientists and clinicians on this subject matter. In this article, we report a case of orthodontically guided eruption of two impacted maxillary canines based on the experience of the Tamil Nadu Government Dental College and Hospital, Chennai, India.
\end{abstract}

Keywords: canine teeth, tooth impacted, orthodontic anchorage procedures

\section{RESUMO}

Caninos impactados correspondem a achados frequentes na população. Os caninos superiores, por sua vez, são de grande importância tanto do ponto de vista estético quanto funcional, dado que esses dentes fornecem suporte para músculos do lábio e da face, atuam como importantes guias da oclusão, desempenham um papel fundamental como suporte tecidual na região do canto da boca e normalmente ocupam posição de destaque na curvatura da arcada dentária. Uma falha de irrupção canina devido à impactação pode afetar a oclusão e até mesmo influenciar o desenvolvimento psicológico das pessoas acometidas. Atualmente, diferentes diretrizes podem ser encontradas na literatura a respeito do manejo de caninos superiores impactados, contudo ainda não há um consenso entre cientistas e clínicos sobre esse assunto. Neste artigo, nós relatamos um caso de irrupção guiada ortodonticamente de dois caninos superiores impactados com base na experiência do Hospital e Faculdade de Odontologia do Governo de Tamil Nadu de Chennai na Índia.

Palavras-chave: dentes caninos, dente impactado, procedimentos de ancoragem ortodôntica

\section{INTRODUCTION}

Impacted tooth is one that is prevented from erupting into position due to different causes such as, malposition, lack of space in the dental arch or other impediments (1). Maxillary canines correspond to the most impacted teeth after the third molars (2). Dental professionals are faced with the dilemma of whether to extract or guide the impacted maxillary tooth into occlusion. The decision to extract is generally considered when the impacted maxillary canine is in an unfavourable position, which can cause complications (3). Because of the significance of maxillary canines to aesthetics and function, such decision can have very serious consequences. Canine position is much important in denture teeth arrangement, since it promotes facial aesthetics by supporting lip and facial muscles, acts as important guideposts in occlusion, plays a vital role as tissue support at the corner of the mouth and its position is in the turning point of the dental arch (4). A failure of tooth eruption due to impaction will affect the occlusion and may even influence the psychological development of the affected people (5).

\footnotetext{
1 Tamil Nadu Government Dental College and Hospital, Chennai, India.

2 Noorul Islam College of Dental Sciences, Thiruvananthapuram, India.

3 Ribeirão Preto Medical School, University of São Paulo, Ribeirão Preto, Brazil.
}

Correspondence: Dr. Marcos Roberto Tovani-Palone
Ribeirão Preto Medical School, University of São Paulo, Ribeirão Preto, Brazil.

E-mail:marcospalone@hotmailcom

E-mail:marcos_palone@hotmail.com

Received: 27 Mar 2019, Accepted: 14 Apr 2019

(C) 2019 by the authors; licensee Modestum Ltd., UK. This article is an open access article distributed under the terms and conditions of the Creative Commons Attribution License (http://creativecommons.org/licenses/by/4.0/). 


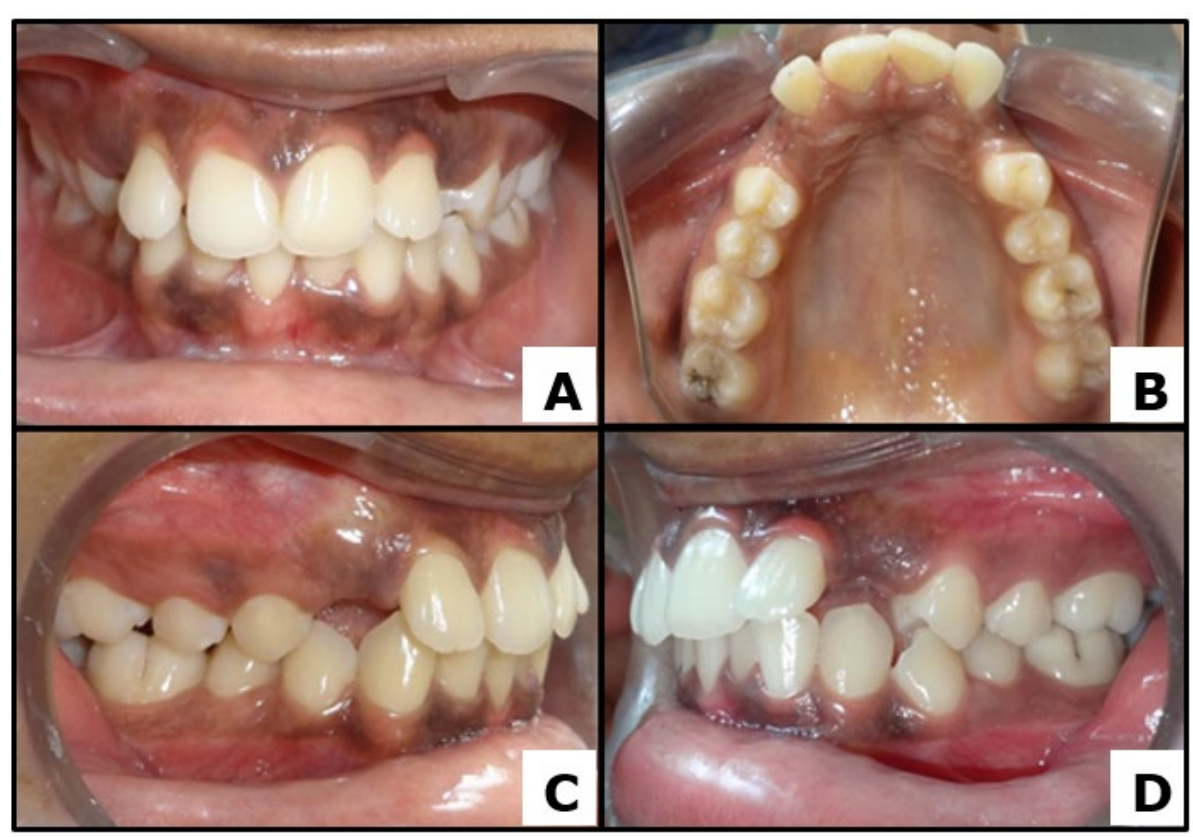

Figure 1: $(A, B, C$ and $D)$ Pretreatment intraoral photographs

Currently there are different guidelines for management of impacted maxillary canine published in the literature $(6,7)$. However, until now, there is still no absolute consensus among scientists and clinicians on the choice of the best treatment protocols for each case. Here, we report a case of orthodontically guided eruption of two impacted maxillary canines based on the experience of the Tamil Nadu Government Dental College and Hospital, Chennai, India.

\section{CASE REPORT}

A 17-year-old female patient came to the Department of Orthodontics of the Tamil Nadu Government Dental College and Hospital, Chennai, India with the chief complaint of missing teeth in the upper arch. No relevant medical and dental history was recorded. She was mesomorphic with an average face height. The patient, moreover, had a convex facial profile, average nasolabial angle and an average mentolabial sulcus.

Intraoral clinical examination showed asymmetric maxillary and mandibular arches, crowding in the anterior region, absence of both the right and left upper canines (Figures 1A, 1B, 1C and 1D), Angle's Class I molar relation and a spaced maxillary arch (Figures 1A, 1C and 1D). There was also mild incisor proclination with an overjet of about $4 \mathrm{~mm}$ (Figures 1C and 1D). The facial midline did not coincide with maxillary and mandibular midline, and the maxillary dental midline was deviated by $1 \mathrm{~mm}$ to the right side (Figure $\mathbf{1 A}$ ).

Investigations: Extra oral and intraoral photographs, study models, intra-oral periapical radiographs, maxillary occlusal radiographs, lateral cephalometric radiograph, panoramic radiograph, functional examination and cone beam computed tomography of the maxillofacial region were conducted. The patient had a normal swallowing pattern, the mandible moved upwards and forwards on closure, $2 \mathrm{~mm}$ of incisor exposure at rest and 100\% incisor exposure during smile.

Study model analysis confirmed the clinical findings, showing the maxillary midline shifted $1 \mathrm{~mm}$ towards the patient's right side. Cephalometric analysis revealed class I skeletal relationship ( $A N B=3.5^{\circ}, B O$ ahead of $A O$ by $0.5 \mathrm{~mm}$ ), orthognathic maxilla $\left(S N A=83.5^{\circ}, \mathrm{N}\right.$ perp $A=1 \mathrm{~mm}$ ) and orthognathic mandible $\left(\mathrm{SNB}=80^{\circ}, \mathrm{N}\right.$ perp pog $\left.=0 \mathrm{~mm}\right)$ in relation to anterior cranial base. Maxillary incisors presented a minimal increase in axial inclination $\left(\perp 1\right.$ to $N A=28^{\circ}$ and $\perp 1$ to $N A=4 \mathrm{~mm}$ ), while mandibular incisors showed a normal axial inclination ( 1 to $N B=26^{\circ}$ and $T 1$ to $N B=5 \mathrm{~mm}$ ).

\section{DIAGNOSTIC AND EVALUATION OF THE MAXILLARY CANINES}

\section{Clinical Assessment}

Visual inspection revealed presence of canine bulge between the lateral incisor and first premolar on the right side (Figure 2A). However, the canine bulge was neither visible nor palpable on the left side and there was a mesial and buccal angulation of the lateral incisor (Figure 2B). 


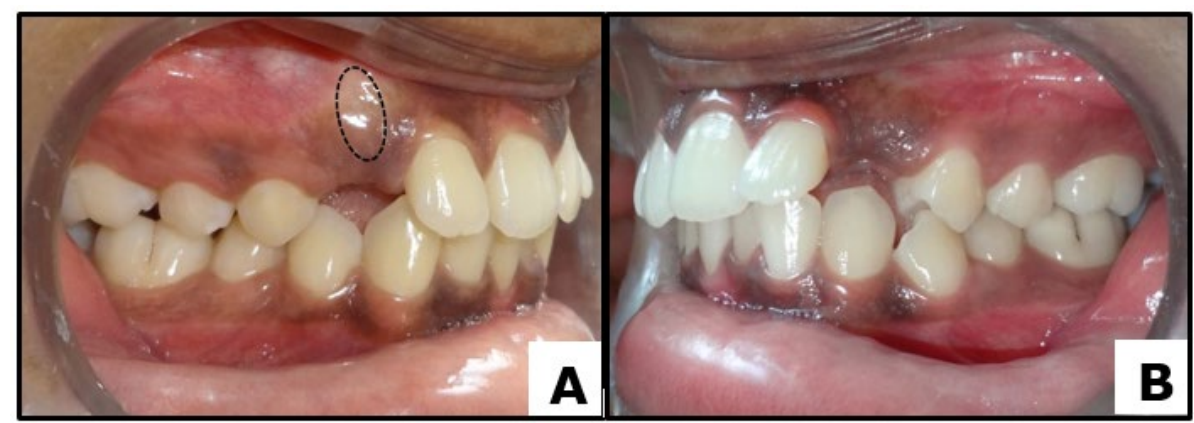

Figure 2: (A) Presence of a canine bulge on the right side. (B) Absence of this structure on the left side

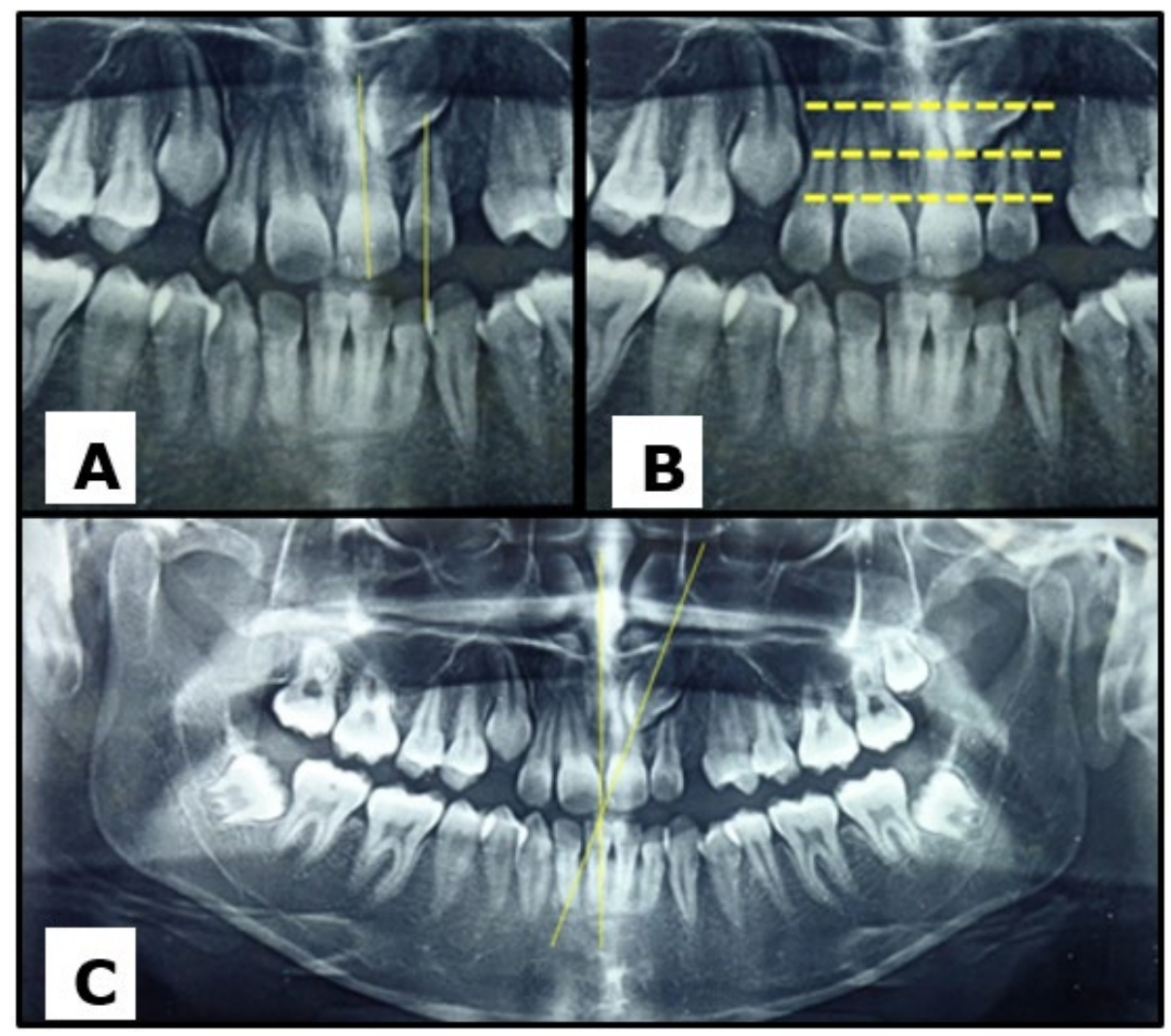

Figure 3: Radiographic assessment of the left maxillary canine. (A) Horizontal, (B) vertical and (C) angular assessments revealed that the tooth was in an unfavourable position for orthodontic treatment

\section{Prognostic Evaluation}

Different aspects of canine position were assessed by radiographs. The prognostic factors investigated by McSherry (8), Pitt, Hamdan and Rock (9) and Counihan, Al-Awadhi and Butler were used as references (10).

$>$ The amount the canine crown that horizontally overlaps the adjacent incisor. In our patient, the left canine was closer to the midline, and not overlapping the adjacent lateral incisor, but the central incisor (Figure 3A), which suggested a poor prognosis.

$>$ Vertical height of the canine crown. In this case report, the crown of the left canine was located more than halfway up the root of the central incisor but less than the full length of the root of this tooth (Figure 3B), indicating an average prognosis.

$>$ Canine angulation to the midline. In this patient, the canines were angulated $30^{\circ}$ and $8^{\circ}$ to the midline on the left and right sides respectively (Figure $\mathbf{3 C}$ ), which suggested an average prognosis to the left canine and a good prognosis to the right canine.

$>$ The position of the canine root apex in the horizontal plane. Cone beam computed tomography revealed that the left canine root apex was positioned above the normal canine position (Figure 4), indicating a good prognosis. 


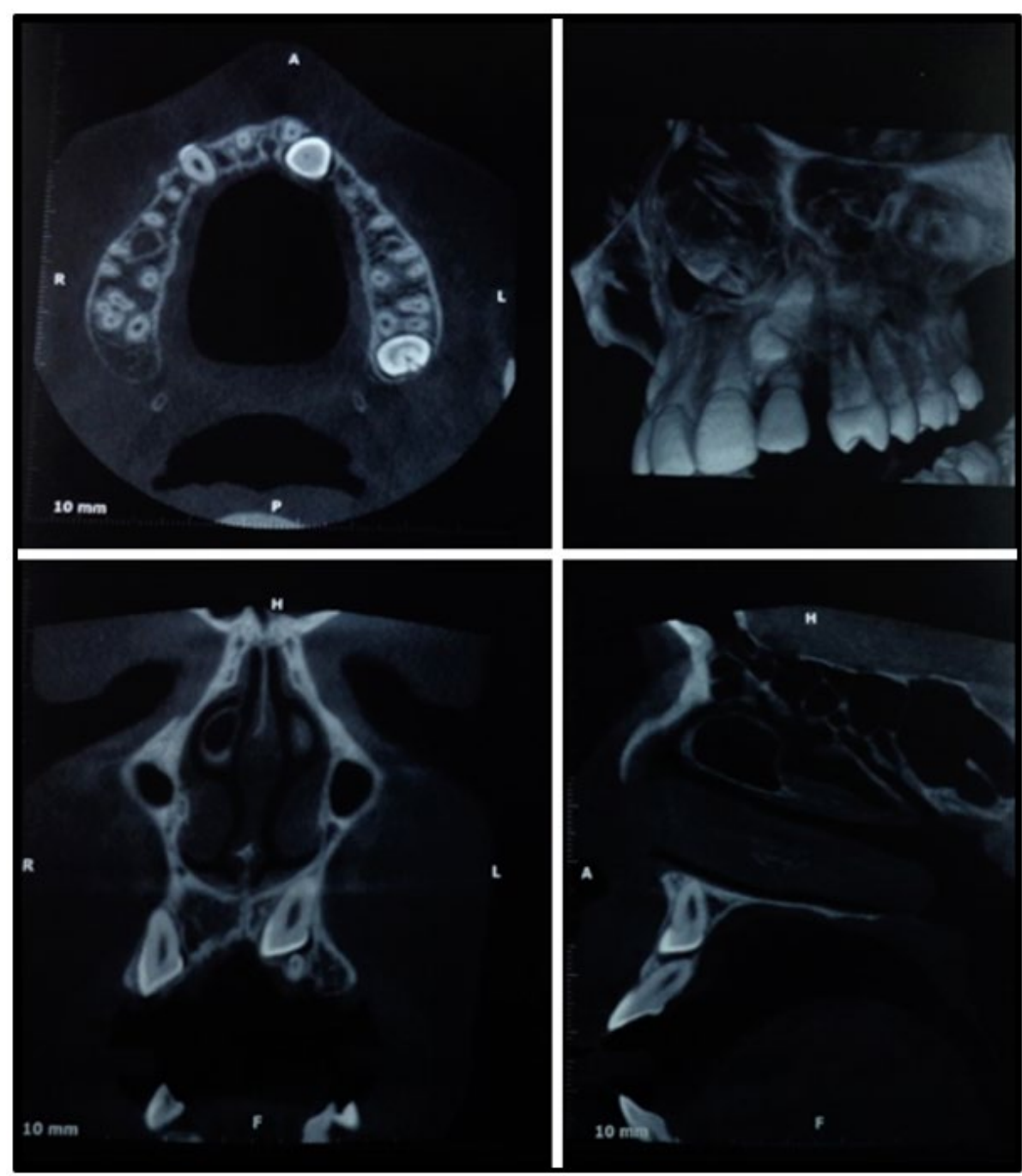

Figure 4: Cone beam computed tomography

Ericson and Kurol in 1988 defined number of sectors to denote different types of impaction (11). The left canine cusp tip was located in the sector 1 with an angulation of $29^{\circ}$, suggesting a poor prognosis.

The case was diagnosed as Angle's Class I malocclusion on a class I skeletal base with an orthognathic maxilla associated with an orthognathic mandible, upper and lower anterior crowding, with impaction of right maxillary canine and left canine with favourable and unfavourable prognostics respectively.

\section{Therapeutic Focus and Treatment}

The patient was very concerned about aesthetics. She was apprehensive regarding the extraction of the left maxillary canine that was in an unfavourable position. Hence we decided to surgically expose both the maxillary right and left canine, followed by orthodontic guided eruption. Combined forced eruption treatment approach was performed at different phases.

1. Anchorage preparation;

2. Surgical exposure of the impacted teeth;

3. Placement of an attachment to the teeth;

4. Application of orthodontic mechanics to align the impacted teeth.

Anchorage preparation. Customized soldered hooks placed on the labial and palatal surfaces were fabricated and cemented along with molar tubes (Figure 5A and 5B). Rhomboid (MBT) brackets were bonded and initial alignment was achieved with the sequence of nickel titanium archwires $0.016,0.18,0.016 \times 0.022,0.017 \times 0.025$. The treatment was followed using $0.017 \times 0.025$ stainless steel wires. The spaces in the upper right and left canine regions were maintained with sleeves inserted between the lateral incisor and first premolars. At this stage, the patient was referred to the Oral and Maxillofacial Surgery Department of our Institution for surgical exposure of the impacted maxillary canines. 


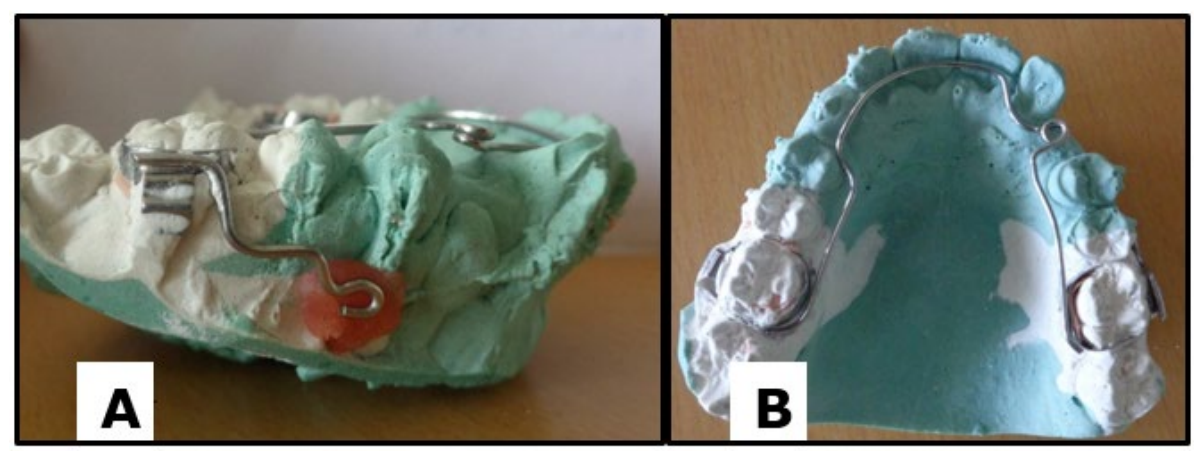

Figure 5: (A and B) Customized soldered hooks

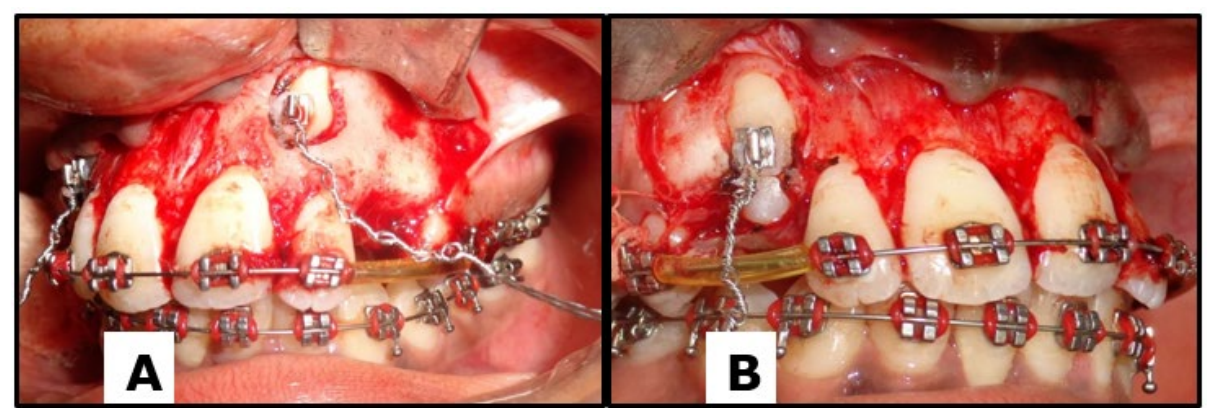

Figure 6: $(A$ and $B)$ Surgical exposure and orthodontic traction

Surgical exposure of the impacted teeth. A closed eruption technique was used. This was due to the fact that the crown of the canines were positioned apical to the mucogingival junction, which makes inappropriate to the case the use of both excisional technique and apically positioned flap $(12,13)$.

Methods for Attachment and traction. A bracket with twisted wire ligatures was bonded to the enamel surface after the surgical exposure of the impacted teeth crown (Figures 6A and 6B). The wire ligatures on the left canine were tied to the anchor hooks on the buccal and palatal aspects (Figure 6A). A distal and occlusal force vector was applied with weekly activation. The right canine was directly connected to the main archwire through a ligature wire (Figure 6B).

Follow-up and Outcome: Favourable clinical results were observed within 9 months from the day of initiation of treatment (Figures 7A, 7B, 7C, 7D, 7E and 7F). The right maxillary canine was brought into occlusion earlier than the one on the left side (Figure 7C). A piggy back wire (Figure 7D) was placed when the left canines crown was fully visible and subsequent to the eruption of the tooth into occlusion. A $0.017 \times 0.025$-in Nitinol wire followed by the same size stainless steel wire were used for orthodontic mechanics. Palatal root torquing of the left canine was achieved using a soldered torquing spur (Figure 7E). 


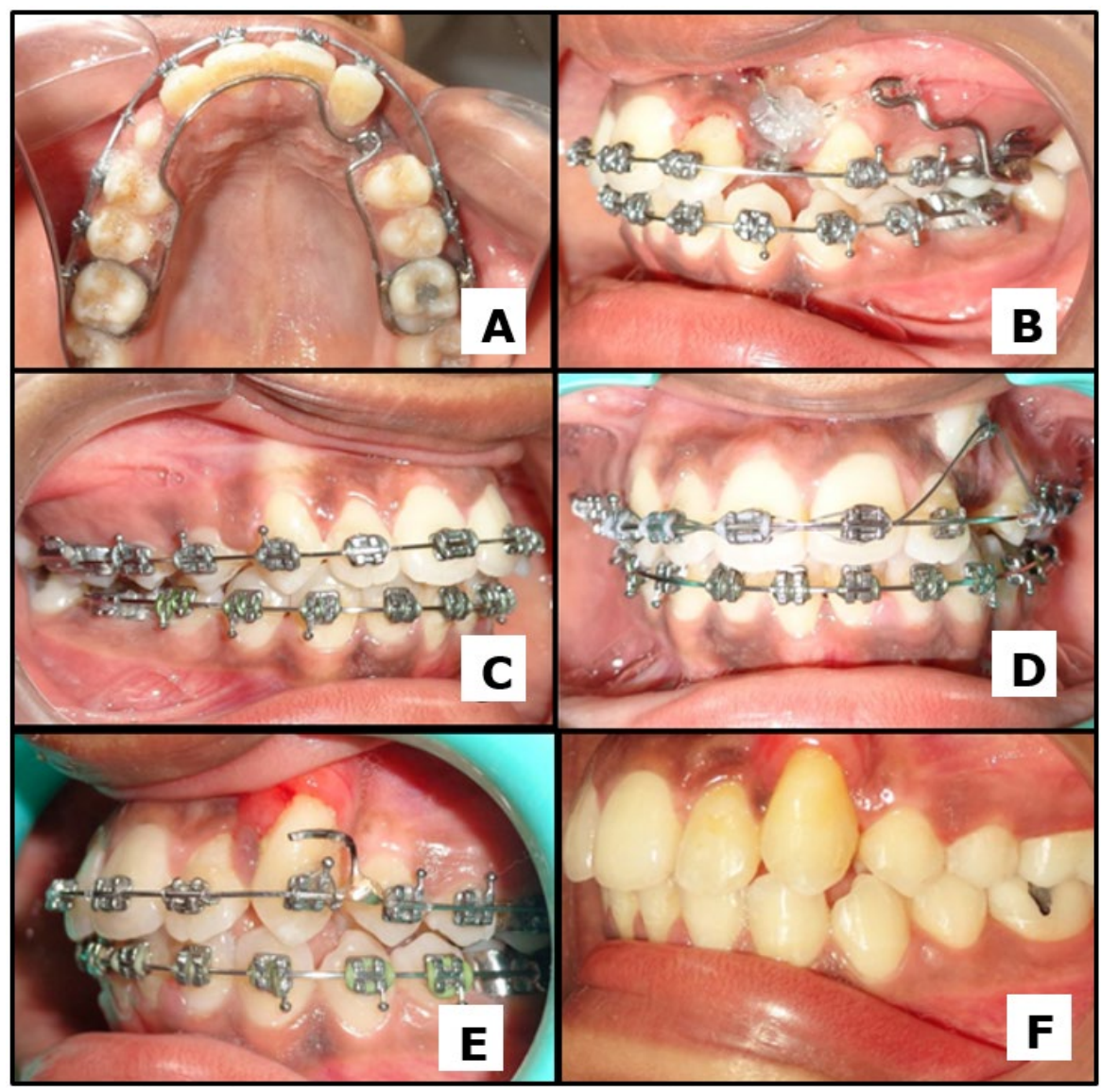

Figure 7: Orthodontic treatment sequence. (A) Right canine was moved. (B) Application of traction force on the left canine. (C) Right canine aligned in the arch. (D) The left canine was moved out of the alveolar bone. A piggyback wire was used. (E) Applying torquing forces to the left canine. (F) Left canine aligned in the arch. Improvement in gingival health can be observed

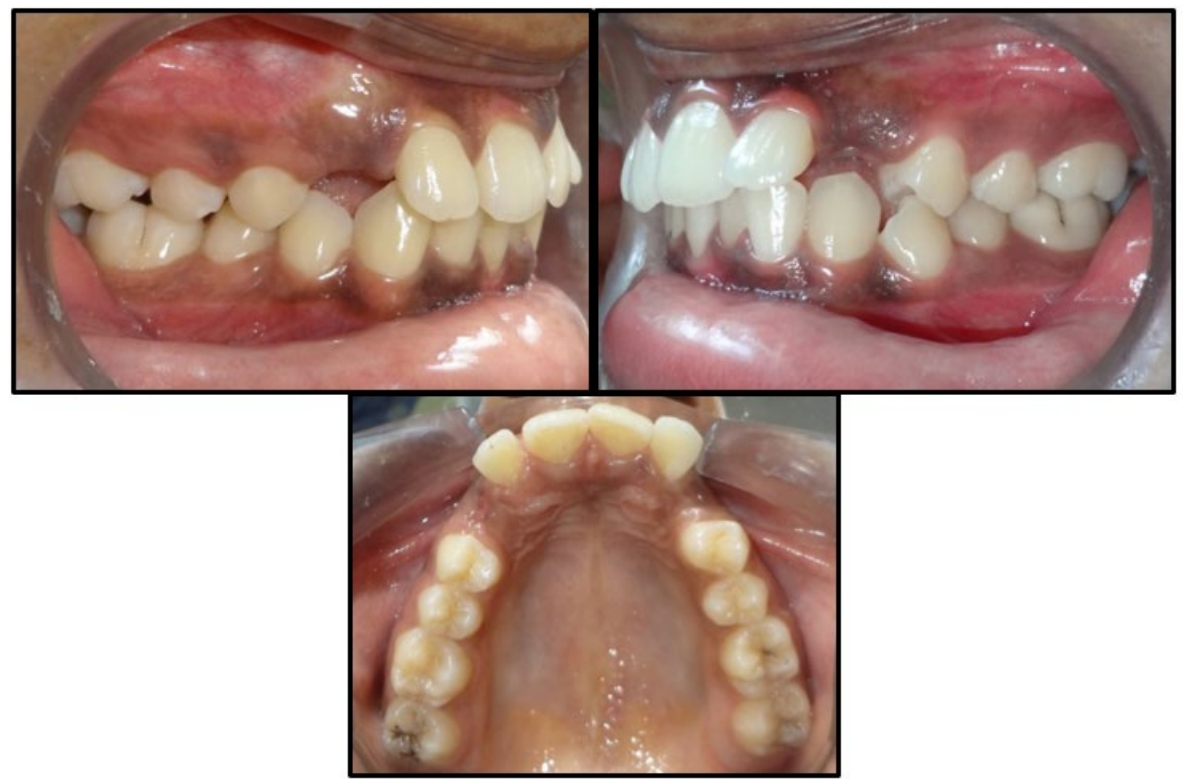

Figure 8: Intraoral photographs. Pre-treatment

At the end of the treatment period, a functional occlusion was observed. The clinical results included normal overjet and overbite, adequate intercuspation, nearly coincident midlines, normal maxillary and mandibular incisor proclination with class I molar relation and class I canine relation bilaterally. The patient was satisfied and the case was finalized. Figures 8 and 9, 10 and $\mathbf{1 1}$ show the radiographic and clinical changes (intraoral and extraoral) achieved with the treatment. 

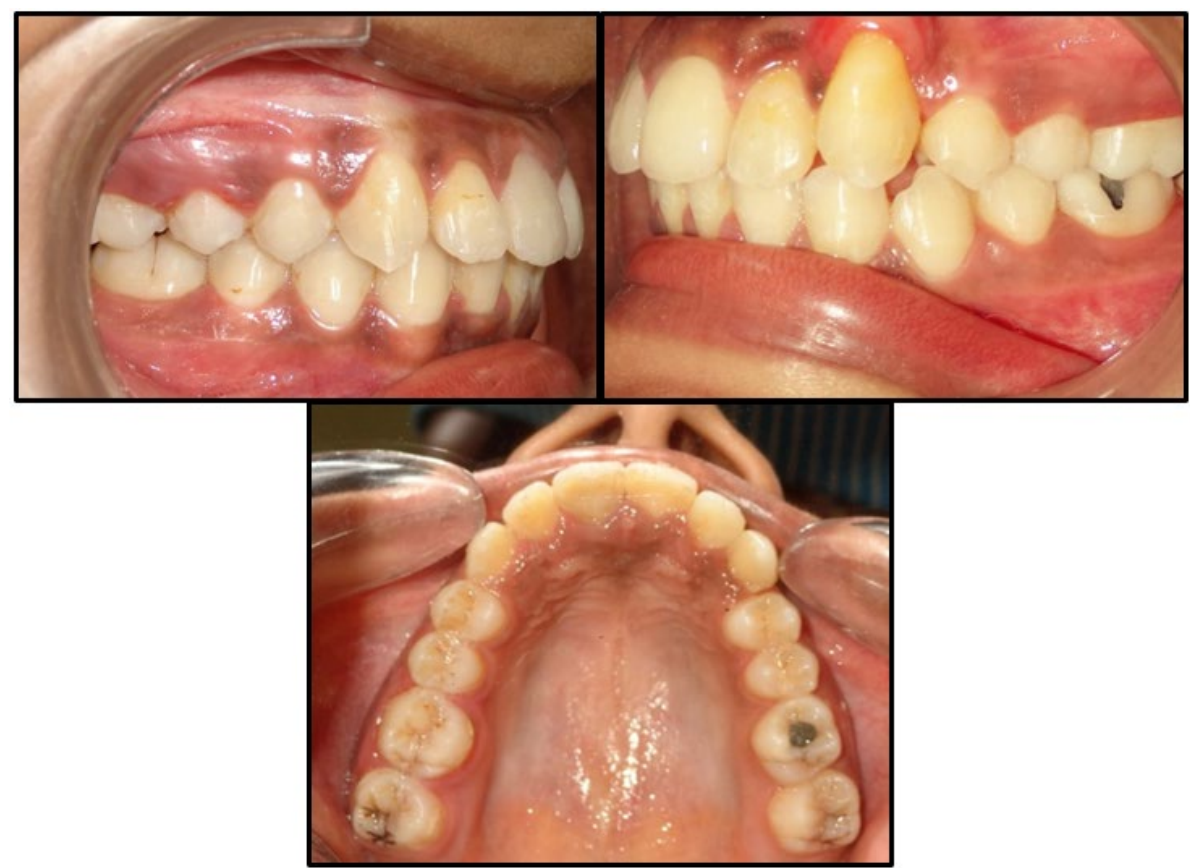

Figure 9: Intraoral photographs. Post-treatment

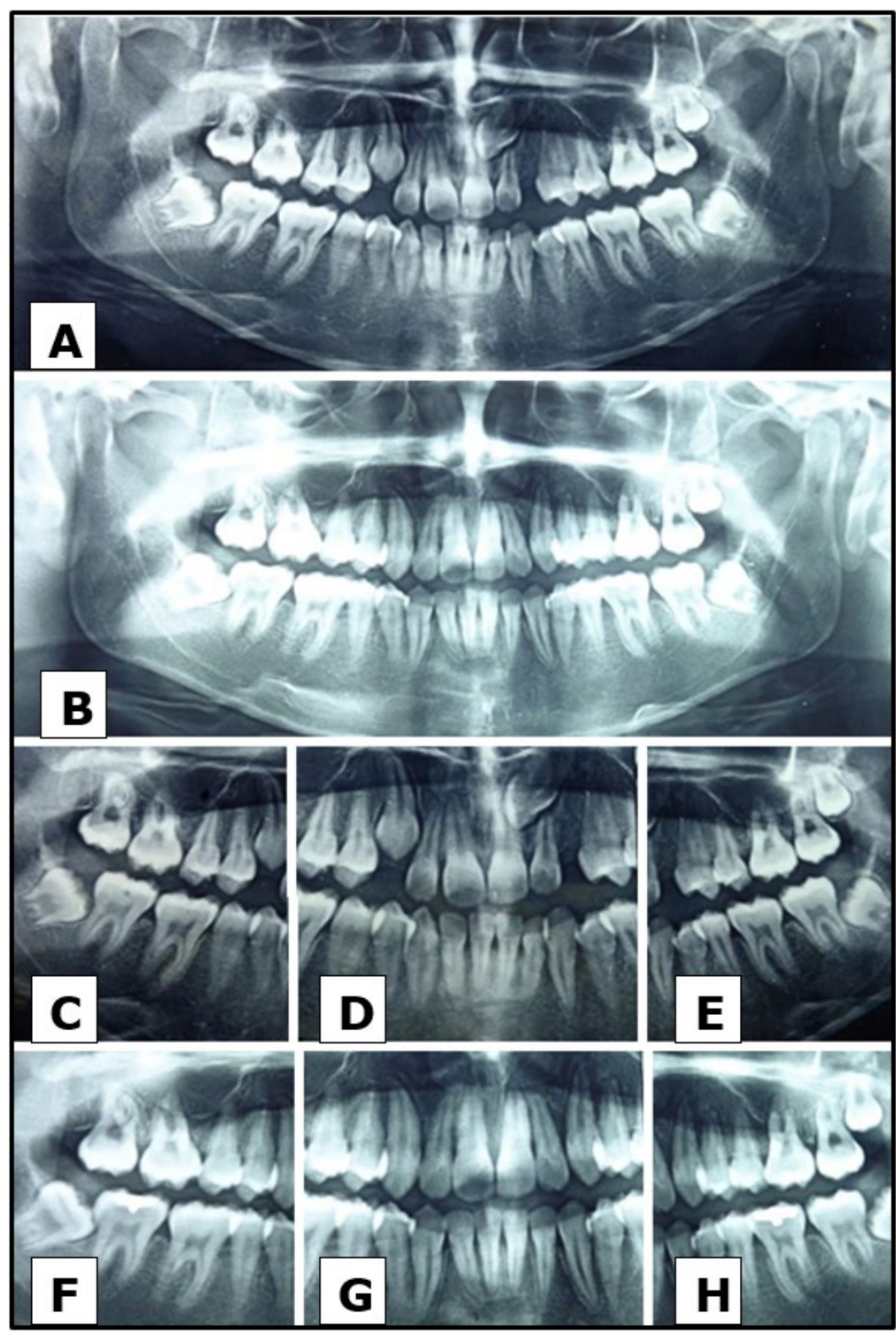

Figure 10: Panoramic radiographs. $(A, C, D$ and $E)$ Pre and $(B, F, G$ and $H)$ post-treatment 


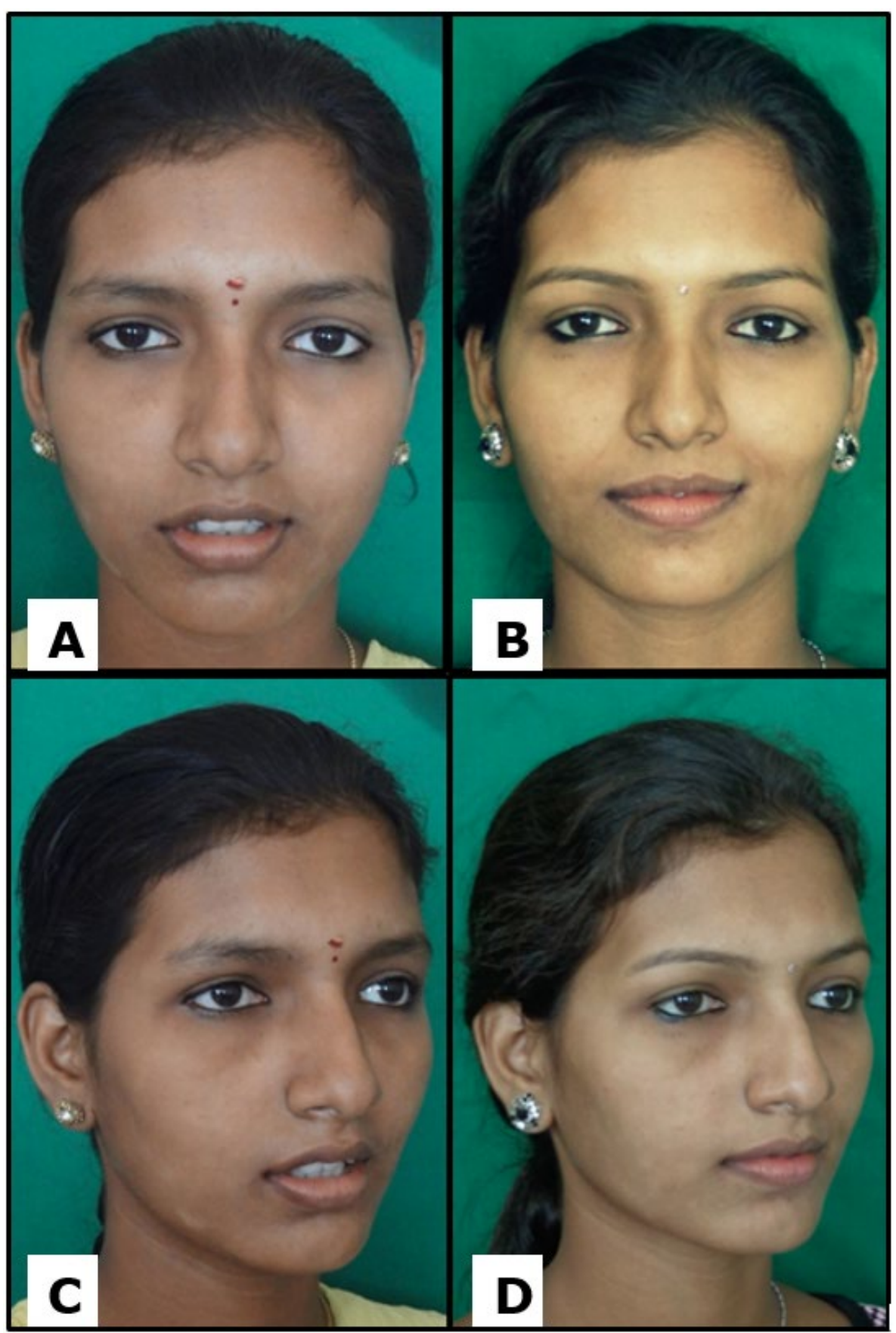

Figure 11: Extraoral photographs. Comparison of ( $A$ and $C)$ pretreatment and (B and D) post-treatment

\section{DISCUSSION}

The development of maxillary canines occurs laterally to the piriform fossa. Such teeth have the most difficult eruption path, the longest period of development and the deepest area of development (14).

According to Coulter and Richardson the maxillary canines travel almost $22 \mathrm{~mm}$ from 5 to 15 years of age in the three planes of space (14). It should also be noted that the tooth eruption comprises a complex and coordinated developmental process requiring a series of signalling effects between the dental follicle and osteoblast, and osteoclast cells found in the alveolar bone (15). Due to this, and their long and tortuous path of travel, maxillary canines are the most frequently impacted teeth after the third molars, with a prevalence of approximately $2 \%(16,17)$.

The etiology of impacted canines comprises a wide variety of localized, systemic, genetic and environmental reasons, ranging from delayed eruption to a complete failure of eruption (18).

In this regard, the local hard tissue obstruction, occurrence of a local pathology, departure from or disturbance of the normal development of the incisors and hereditary or genetic factors are important causes to be considered (19). Such 
causes include febrile diseases, endocrine disorders, irradiation, arch length discrepancies, prolonged retention, tooth size, early loss of the deciduous canine, supernumerary teeth, ankylosis, alveolar cleft and apical periodontitis of deciduous teeth (18).

In the present case report, important evaluations on the prognostic criteria for impacted maxillary canines like the horizontal overlap of the canine crown over the lateral incisor, vertical height of the canine crown, canine angulation to the midline, position of the canine root apex and sector analysis, were carried out (Figures $\mathbf{3}$ and 4). The only favourable prognostic factor identified in our patient was the correct position of the canine root apex. Considering this finding, we decided not to extract the left canine and the orthodontic guided eruption was the method of choice for this case. Moreover, given that the treatment of an impacted maxillary canine is not completed merely with its orthodontic alignment (20), the treatment followed was: alignment and levelling, anchorage preparation, surgical exposure with closed eruption technique, bonding of attachment, traction force application, and final detailing.

Another relevant point is that the final periodontal health is essential to evaluate the success of therapy for impacted maxillary canines (20). In our patient, the periodontal health in the left maxillary canine region was restored after orthodontic treatment with use of periodontal therapy.

The overall combined treatment performed in our Institution was divided into five phases. We believe that these steps should be indispensable for successful treatment of many cases of impacted maxillary canines.

- Phase 1: Initial orthodontic treatment aimed at maintaining the space on the maxillary arch and alignment and levelling by means of fixed appliance therapy.

- Phase 2: Use of customized soldered anchorage preparation and a rectangular stabilization arch to obtain adequate anchorage and maintain sufficient space in the dental arch.

- Phase 3: Surgical exposure and orthodontic traction of the impacted maxillary canine towards the center of the alveolar ridge.

- Phase 4: Final orthodontic treatment to align the impacted tooth in the maxillary arch.

- Phase 5: Periodontal treatment after orthodontic therapy to restore the periodontal health.

\section{FINAL CONSIDERATION}

Impacted maxillary canines are frequently encountered and it is important for dental surgeons to be aware of the different techniques available for management of these teeth. Moreover, the extraction of impacted maxillary canines should not be the first choice in the majority of cases. In this regard, a successful management is, undoubtedly, of great importance for both related aesthetic and functional aspects.

\section{Patient Consent}

The patient has provided written informed consent.

\section{REFERENCES}

1. Walters H. Lower third molar treatment. Br Dent J. 1997;182(6):207. https://doi.org/10.1038/sj.bdj.4809347 PMid:9115836

2. Bishara SE. Clinical management of impacted maxillary canines. Semin Orthod. 1998; 4(2):87-98. https://doi.org/10.1016/S1073-8746(98)80006-6

3. Sajnani AK, King NM. Complications associated with the occurrence and treatment of impacted maxillary canines. Singapore Dent J. 2014;35:53-7. https://doi.org/10.1016/j.sdj.2014.07.001 PMid:25496586

4. Sinavarat $P$, Anunmana $C$, Hossain $S$. The relationship of maxillary canines to the facial anatomical landmarks in a group of Thai people. J Adv Prosthodont. 2013; 5(4):369-73. https://doi.org/10.4047/jap.2013.5.4.369 PMid:24353872 PMCid:PMC3865189

5. Seehra J, Yaqoob O, Patel S, et al. National clinical guidelines for the management of unerupted maxillary incisors in children. Br Dent J. 2018; 224(10):779-85. https://doi.org/10.1038/sj.bdj.2018.361 PMid:29795486

6. Spuntarelli M, Cecchetti F, Arcuri L, et al. Combined orthodontic-surgical approach in the treatment of impacted maxillary canines: three clinical cases. Oral Implantol (Rome). 2016; 8(2-3):63-7.

7. Raghav $P$, Singh $K$, Munish Reddy $C$, Joshi D, Jain S. Treatment of maxillary impacted canine using ballista spring and orthodontic wire traction. Int J Clin Pediatr Dent. 2017; 10(3):313-7. https://doi.org/10.5005/jp-journals10005-1457 PMid:29104396 PMCid:PMC5661050 
8. McSherry PF. The assessment of and treatment options for the buried maxillary canine. Dent Update. 1996;23(1):7-10

9. Pitt S, Hamdan A, Rock P. A treatment difficulty index for unerupted maxillary canines. Eur J Orthod. 2006;28(2):141-4. https://doi.org/10.1093/ejo/cji068 PMid:16043468

10. Counihan K, Al-Awadhi EA, Butler J. Guidelines for the assessment of the impacted maxillary canine. Dent Update. 2013; 40(9):770-2, 775-7. https://doi.org/10.12968/denu.2013.40.9.770 PMid:24386769

11. Ericson S, Kurol J. Early treatment of palatally erupting maxillary canines by extraction of the primary canines. Eur J Orthod. 1988;10(4):283-95. https://doi.org/10.1093/ejo/10.4.283 PMid:3208843

12. Kokich VG, Mathews DP. Surgical and orthodontic management of impacted teeth. Dent Clin North Am. 1993;37(2):181-204.

13. Becker A, Brin I, Ben-Bassat Y, Zilberman Y, Chaushu S. Closed-eruption surgical technique for impacted maxillary incisors: a postorthodontic periodontal evaluation. Am J Orthod Dentofacial Orthop. 2002;122(1):9-14. https://doi.org/10.1067/mod.2002.124998 PMid:12142887

14. Coulter J, Richardson A. Normal eruption of the maxillary canine quantified in three dimensions. Eur J Orthod. 1997;19(2):171-83. https://doi.org/10.1093/ejo/19.2.171 PMid:9183067

15. Suri L, Gagari E, Vastardis H. Delayed tooth eruption: pathogenesis, diagnosis, and treatment. A literature review. Am J Orthod Dentofacial Orthop. 2004;126(4):432-45. https://doi.org/10.1016/j.ajodo.2003.10.031 PMid:15470346

16. Sajnani AK, King NM. Prevalence and characteristics of impacted maxillary canines in Southern Chinese children and adolescents. J Investig Clin Dent. 2014;5(1):38-44. https://doi.org/10.1111/jicd.12027 PMid:23355390

17. Alhammadi MS, Asiri HA, Almashraqi AA. Incidence, severity and orthodontic treatment difficulty index of impacted canines in Saudi population. J Clin Exp Dent. 2018;10(4):e327-e334. https://doi.org/10.4317/jced.54385 PMid:29750092 PMCid:PMC5937966

18. Ngan $P$, Hornbrook R, Weaver B. Early timely management of ectopically erupting maxillary canines. Semin Orthod. 2005;11(3):152-63. https://doi.org/10.1053/j.sodo.2005.04.009

19. Becker A, Chaushu S. Etiology of maxillary canine impaction: a review. Am J Orthod Dentofacial Orthop. 2015;148(4):557-67. https://doi.org/10.1016/j.ajodo.2015.06.013 PMid:26432311

20. Crescini A, Nieri M, Buti J, Baccetti T, Pini Prato GP. Orthodontic and periodontal outcomes of treated impacted maxillary canines. Angle Orthod. 2007; 77(4):571-7. https://doi.org/10.2319/080406-318.1 PMid:17605500

$\diamond \diamond \diamond \diamond \diamond \diamond \diamond$

http://www.ejgm.co.uk 